This item is the archived peer-reviewed author-version of:

The odd one out: The influence of ideological positioning on individual electoral success

\title{
Reference:
}

Van Erkel Patrick.- The odd one out: The influence of ideological positioning on individual electoral success

Party politics - ISSN 1354-0688 - (2021)

Full text (Publisher's DOI): https://doi.org/10.1177/13540688211050065

To cite this reference: $\mathrm{https}: / / \mathrm{hdl}$.handle.net/10067/1821170151162165141 


\section{The odd one out: The influence of ideological positioning on individual electoral success}

Patrick van Erkel - University of Antwerp

Within many countries voters not only have to cast a vote for a political party, but also have the option to select (a) candidate(s) within that party, a so-called preferential vote. Recent studies indicate that several factors influence the success of candidates within this intra-party competition, such as ballot list position, political experience, and socio-demographic characteristics. However, it has not yet been investigated whether ideology also matters for intra-party success. This study investigates the role of the ideological position of candidates within their party on the share of preferential votes they obtain. Can candidates win preferential votes by taking ideological niche positions within the party? To investigate this question the study uses data from a candidate survey conducted during the 2014 Belgian elections in which candidates were asked to position themselves ideologically. The results of this study indicate that ideology does not play a strong role within the intra-party competition.

Keywords: Preferential voting, Ideology, Political candidates, Elections

Biography: Patrick van Erkel is a postdoctoral researcher at the Department of Political Science of the University of Antwerp, where he is connected to the research group $\mathrm{M}^{2} \mathrm{P}$ (Media, Movement and Politics). His research interests include electoral behaviour, public opinion, political communication and polarization.

Contact: Patrick.vanErkel@uantwerpen.be

Word count: 7999 


\section{Introduction}

Elections form the cornerstone of democracy in which parties compete with each other to win seats in parliament and to get elected into government (Downs, 1957). However, in many systems, such as proportional systems with an open or flexible list, elections not only consist of an inter-party competition, but also of a competition between candidates within the same political party, the intraparty competition. Unlike closed list systems, in open or flexible list systems, voters not only have to choose between parties, but also have to cast a vote for one or more political candidates on the party list, so-called preferential votes. For many contenders these preferential votes are crucial as they partly (flexible lists) or fully (open lists) determine which candidates from the party get a seat in parliament. Moreover, the amount of preferential votes obtained is important for internal power within a party, as candidates who won many preferential votes have a good chance of becoming mayor or minister (Folke et al., 2016; Wauters et al., 2012) and a higher chance to get a good position on the ballot list on the next elections (André et al., 2017).

As preferential votes are such a crucial resource for candidates, scholars increasingly started to investigate what drives this individual electoral success and based on recent studies we know that that there are a number of factors that explain it. These studies point, for instance, to structural factors such as ballot list position (Marcinkiewicz \& Stegmaier, 2015; van Erkel \& Thijssen, 2016), but also to so-called personal vote-earning attributes (PVEAs) (Shugart et al., 2005). Although the concept of PVEAs was originally mostly used in relation to attributes connected to the localness of candidates, e.g. birthplace and lower level political experience, later the concept has been broadened to include all attributes related to the individual characteristics and reputation of candidates (Put et al., 2019). Studies have shown that a wide arrange of PVEAs, such as gender, ethnicity, local experience, media attention, but also physical appearance, all have an influence on the number of preferential votes candidates receive (e.g. Maddens et al., 2006; Marien et al., 2017; van Erkel, 2019).

However, one potential PVEA has so far been overlooked in the literature, namely the individual ideological position of a political candidate within her party. From the literature on party voting, we know that in general ideology matters. Even though the extent is debated, there is no doubt that for many voters ideology plays an important role in their vote decision (Alvarez \& Nagler, 1998). This raises the question to what extent ideology also matters in the intra-party competition. Can candidates win preferential votes by taking an ideological niche position within the party? Or will they be electorally punished for deviating and is it therefore better to stick to the party line instead? So far, no studies have investigated this in a multi-party system for political candidates. There is literature on how homogenous parties are, showing that often parties are ideological somewhat diverse and, in certain situations, can consist of multiple internal fractions (Andeweg \& Thomassen, 
2011; Van Haute \& Carty, 2012). Yet, to what extent the ideological position of individual candidates influences voters in their decision regarding preferential votes, remains unclear. Using data from a candidate survey conducted during the Belgian 2014 elections, the aim of this study is to look into this question and assess the role of ideology on the individual electoral success of candidates. This is not only important to better understand what explains individual electoral success in (semi-)open list systems, but also to shed more light on how and why citizens use preferential votes. Do citizens solely cast preferential votes for certain candidates on the basis of features such as socio-demographic characteristics, thus using them more as an expressive instrument to support certain marginalized groups, or do they also cast preferential votes on the basis of the ideology of a candidate, and thus use them also to signal the party on where it should stand ideologically?

\section{Party heterogeneity, ideological positioning and its electoral impact}

Although we often consider political parties to be unitary actors when examining their role in coalition formations (Laver \& Schofield, 1998), their strategic aims (Müller \& Strøm, 1999), or the way parties shape the ideological space (e.g. Downs, 1957), parties are in fact far from unitary. In his seminal work Parties and Party systems, Sartori (1976) already took this into account by studying the formation of different ideological factions within parties. Others have followed up on this by focusing on defecting voting behavior in parliament, assessing to what extent MPs of a party vote the same in parliament (e.g. Bowler, 2010; Ceron, 2015). These studies demonstrate that MPs do not always vote according to the party line, although this defection is less prevalent in systems where party discipline is higher, such as Belgium and the Netherlands (Andeweg \& Thomassen, 2011). Nevertheless, also in these countries it is inevitable that there are candidates within the party that ideologically deviate from the party line. In Belgium, for instance, parties compete with large ballot lists in multiple districts. To fill all these positions on their lists they often have to rely on local office holders and rank-and-file members; candidates that, based on May's law of curvilinear disparity, can be expected to hold more extreme views than the party leadership (May, 1973). ${ }^{1}$ Van Haute and Carty (2012) indeed show that within all Belgian parties, there is a substantial group (10 to $20 \%$ ) of ideological 'misfits' that are not ideologically in line with their party, although these misfits are somewhat more prevalent within left-wing parties. More recently, Lesschaeve et al. (2018) also demonstrate that candidates running for the 2014 Belgian elections were not always congruent with their parties and that some take a deviating ideological position, especially on issues that are not owned by the party.

\footnotetext{
${ }^{1}$ May's law is somewhat contested, however, and has not always been empirically supported, see for instance van Holsteyn et al. (2017).
} 
The question then arises to what extent a deviating ideological positioning of candidates within a party impacts their individual electoral success. Can candidates win preferential votes by occupying a unique ideological position within their party? Or does this this hurt their electoral success? Both options seem theoretically plausible; ideology could have a positive effect on the number of preferential votes a candidate obtains, but voters may also electorally punish candidates who diverge from the party line.

Regarding the positive effect, taking an ideological niche position within the party could be an important PVEA and may be a successful strategy for candidates to win preferential votes. By slightly deviating from the official party line candidates can distinguish themselves from their peers. Of course, there are limits to the ideological movement space of candidates, as diverging from the party line too far may actually push voters away, or make it impossible to get on the party's ballot list in the first place. Nevertheless, deviating slightly from the official party line could be a successful way to draw attention on oneself. This is especially important in the PR flexible and open list systems where parties often draft long lists and where it is crucial for candidates to stand out. Or as Carey \& Shugart stated (1995:430) 'as the number of other copartisans from which a given candidate must distinguish herself grows, the importance of establishing a unique personal reputation, distinct from that of the party, also grows'. Taking an ideological niche position in the party may be a successful way to establish such a unique personal reputation.

Another reason why the ideological position of candidates may matter is that the electorate of a party may not always be homogenous. Voters may agree with a party on most ideological dimensions, but take a slightly different stance on others. Candidates that take a niche position within the party may attract this niche group of the electorate, as these voters will feel better (ideologically) represented by this candidate or even vote for this candidate as a signal to the party on where they believe it should stand ideologically. Thus, slightly deviating from the party line could be a more successful strategy for candidates than being fully in line with the party position which is already 'overpopulated' by other candidates. Moreover, in a multi-party system, this strategy could also win over voters from parties that are ideologically closely related.

Of course, one could also hypothesize that deviating from the party line works against the individual electoral success of candidates. Candidates who are not fully congruent with the official party line may be punished by their party's electorate for not 'staying on message' (Norris et al., 1999). Studies by van Holsteyn \& Andeweg (2010) in the Netherlands and by André et al. (2017) in Belgium demonstrate that for most citizens in these countries the vote decision actually follows a two-stage process, where they first decide which party they vote for and only then decide whether to cast a preferential vote and for whom. Given that the preferential vote is thus strongly embedded in the 
party vote, voters may not appreciate it when a candidate does not follow this party line. Especially in more fragmented multiparty systems, such as Belgium, deviating from the party line may be a risky strategy for candidates since there are many ideological close alternative parties available. Thus, when voters want a different ideological course for the party, they may be more likely to vote for one of the other parties, rather than express a preference for a candidate that is taking a niche position within the party. In sum, it may be a more successful strategy for candidates to stay close to the official party line and thereby to position close to the 'median voter' of the own electorate.

Of course, the ideological positioning of candidates may also have no electoral effect at all. Previous studies showed that for voters it is already difficult to position political parties on ideological dimensions and issues (Vegetti et al., 2017). Positioning individual candidates from those parties will be even more difficult. Many citizens may simply not have the political knowledge or interest to know where candidates stand and will not be aware of minor ideological differences within a party. Additionally, even for citizens who would have the resources and interest, this information may simply not be available. Political candidates usually do not present an individual ideological platform and also in the media there is usually no coverage about the individual ideological position of a candidate, unless it really leads to conflict within the party. Therefore, given the fact that the positioning of candidates within a party is cognitively demanding for voters and given that not much information is available, the ideological position of candidates within a party may play no role at all and instead voters may refrain to less cognitively demanding heuristics, such as ballot list position, gender, or political experience when deciding which candidate(s) to give a preferential vote to.

In order to test whether the ideological position of individual candidates within the party impacts their electoral success and based on the possibilities mentioned above of it having a positive a negative or no effect at all, two rivaling hypotheses are formulated that can be contrasted to the null-hypothesis that there is no effect of ideology on the number of preferential votes obtained:

H1a: Candidates that take an ideological niche position within the party and deviate from the ideology of the party are electorally more successful.

H1b: Candidates that remain ideological closer to the party's ideology are electorally more successful.

Of course, it could be that ideology may not work across the board, but only impacts the electoral success of some candidates. As party ballot lists in Belgium are long, ranging between 12 and 33 candidates depending on the district, it is unlikely that voters have information on the ideological positioning of all candidates. However, they may have an indication of the ideological position for 
candidates on top positions of the ballot lists, and know whether these candidates are, for instance, more part of the economic left or right wing of a party. Hence, it could be that while for most of the candidates their ideological position vis-à-vis the party will not play a role, it does matter, either positively or negatively, for candidates on the top positions of the ballot list. To define these top candidates we follow Put \& Maddens (2013) and focus on the realistic candidates; candidates at the top of the list who are almost certain to get elected. However, given that some parties with a high party magnitude can have up to seven realistic candidates, I limit the conceptualization of top candidates to a maximum of the first three realistic candidates on the list. Further nuance could be made here though, as this may apply particularly to top candidates that do not occupy the first position on the ballot list. The reason is that casting a vote on the basis of ideological considerations assumes quite some sophistication from voters, whereas previous studies demonstrate that preferential votes for the head of the list, the so-called list puller, tend to be more cast by less sophisticated voters (van Erkel \& Thijssen, 2016).

H2: The effect of ideological positioning on individual electoral success only matters for top candidates.

Political parties have to take a stance on different issues linked to different ideological dimensions, such as the economy, immigration and Europe. From the literature we know that the salience of these issues differs per party. Also the theory of issue ownership states that voters associate certain issues more with certain parties (Petrocik, 1996). It is on these owned issues that parties are deemed most competent by the voter and voters could base their party choice on the party that they see as the owner on the issue that matters most to them (Green \& Hobolt, 2008). Thus, a voter finding immigration the most important topic, may vote for a party that is considered to own immigration. Consequently, the effect of a candidate slightly deviating from the party line could potentially differ based on whether they distinguish themselves on an owned dimension or not. For instance, we may expect that on owned issues candidates get electorally punished when not following the party line. Given that many voters will choose their party based on the stance on the owned issue, they may not vote for candidates that do not follow this line, i.e. a green candidate taking a different stance on the issue of environment. Alternatively, ideological repositioning may be rewarded on dimensions that are not owned by the party. If voters indeed select parties based on the owned issues they may not always be fully congruent with the party on other issues/ideological dimensions. Consequently, they may vote for a candidate who deviates somewhat from the official party platform on these other dimensions. To stay with the example of the Greens, perhaps some Green voters vote for this party for environmental reasons, but are slightly more right-wing on the economy dimension. A candidate of 
the Greens could jump in this niche position and position herself more right-wing to the party in order to attract the preferential votes of these voters. In sum, we may find different effects of the candidate's ideological position vis-à-vis the party between the issues/ideological dimensions that their party owns and the other issues. I therefore formulate the following hypotheses:

H3a: Deviating from the official party line will have a negative effect on the electoral success of candidates for issues owned by the party.

H3b: Deviating from the official party line will have a positive effect on the electoral success of candidates for issues not owned by the party.

\section{Data and method}

To test the hypotheses, I use data from the 2014 Belgian elections for the federal and Flemish parliament. Belgium is a federal state, characterized by three separate regions; Flanders, Wallonia, and Brussels, each with their own party system, political candidates and media system. Citizens from one region cannot vote for parties or candidates from the other region, nor really follow the news from the other region. Therefore, we focus specifically on Flanders, the Dutch-speaking part of Belgium, reflecting over $60 \%$ of the population. It is a clear example of a PR system with a flexible list (Deschouwer, 2012), as which candidates from the political party receive a seat in parliament is determined via a combination of the ballot list order and the number of preferential votes obtained. Concretely, this means that political parties determine the order of their ballot list beforehand, but that citizens can still change this order. Citizens can opt for two kinds of votes: a list vote or a preferential vote. When citizens cast a list vote they vote for the party as a whole and agree with the order in which candidates are presented on the ballot list. With a preferential vote rather support one or multiple candidates. Belgian voters can cast as many preferential votes as they want, as long as these candidates belong to the same party. Candidates receiving enough preferential votes to surpass a quota immediately get elected. Other candidates can complement their pool of votes using list votes. These votes first go to the number one on the list, until (s)he has enough votes to reach the quota, then to the number two, etc. Once half of the list votes are distributed, the last empty seats, if any left, go to the remaining candidates with the most preferential votes. Although the Belgian flexible list system provides candidates with the opportunity to get elected out of order, in practice only few candidates succeed in this. In 2014 only eight candidates managed to get elected via 
preferential votes for the Flemish parliament and two Flemish candidates managed to do so for the federal parliament.

For the analyses, I use data from a candidate survey. In the months before the 2014 elections 1435 candidates electable in Flanders for the Flemish and federal parliament received an online questionnaire. 899 candidates (62.6\%) fully completed this questionnaire. In the survey, candidates answered a large number of questions, including a battery of 30 ideological statements on six dimensions: Economy, Migration, Environment, Europe, Ethics, and Federalism. I use sub-dimensions, rather than a general left-right dimension, since this enables to tease out the effects of ideology in more detail. The answers on these questions were not only used for this paper, but also for a voting advice application that was developed together with De Morgen, a Flemish newspaper. One can argue that the questions therefore do not measure the real ideological position of candidates, as they may slightly change their position in campaign time for strategical reasons. However, I argue that for the aim of this study this is actually a more valid measurement, since it is exactly the ideological image that candidates communicate to their voters which I am interested in. The 30 ideological questions are all statements on which candidates had to indicate to what extent they agree, ranging from 1 (no agreement) to 7 (full agreement). The items are recoded so that they are all in the same direction, with higher scores indicating more rightwing/authoritarian/Eurosceptical attitudes. Although each dimension was measured using five questions, only the four questions with the highest factor loading in a principal component analysis are used. Almost all factor loadings are above .7, with the exception of one item that has a loading of .68. For the environment sub-dimension only three items have a sufficient loading. All scales have a Cronbach's alpha above .7. In the end six ideological dimension scales are constructed with values ranging between 4 to 28 . The exception is the environment scale that runs from 3 to 21 , as only three items scale sufficiently. An overview of the statements, the principal component analysis and the reliability scores is presented in appendix A.

To operationalize the ideological position of candidates in relation to their party, first the average position of all candidates is aggregated to represent the party's position. This procedure has been used in previous research and generates a valid indication of the official party line ([Author], 2017). One could argue that this average position should not be based on all candidates, but only on those elected in parliament. However, that alternative measure does not result in very different average positions. Next, the absolute deviation is calculated by taking the absolute value of the score obtained after subtracting the party's average position from the candidate's position. This new indicator measures the absolute ideological difference between party and candidates on each dimension. Low scores mean that the candidate is very much in line with the party, whereas high score indicate that the candidate deviates strongly from the party line. In addition, an alternative measure 
is used - directly subtracting the score of the candidate from the party score - which takes into account the direction of the deviation, as a deviation from the party to the left may affect the results differently than a deviation to the right. The first measure is labeled absolute distance and the second measure directional distance. The hypotheses are tested with both measures.

For the dependent variable, individual electoral success, the share of preferential votes obtained is used. For this I create a relative measure. There are two ways to do so. One could divide the number of preferential votes for a candidate by the total number of preferential votes for all candidates on the ballot list, the so-called list proportion, or one could divide the number of preferential votes by the total number of preferential votes for all candidates within the district, the district proportion. For this study I use the district proportion. The reason is that this measure better takes into account the inter-party competition, which may also play a role here, given that with their ideological position candidates may also attract voters that normally vote for other (ideologically related) parties. The effect of ideology may not be just limited to the voters of a candidate's own party, but may also affect voters from other parties. To account for the skewed distribution, the dependent variable is transformed logarithmically.

As independent variables, the constructed ideological difference measures for each dimension are added. Additionally, the models control for some important alternative explanations that are known to affect individual electoral success; gender, ethnicity, political experience, media attention and ballot list position. Gender and ethnic minority are two dummy variables. For gender candidates who self-identified as male were given a score of 0 and candidates who self-identified as female were given a score of $1 .^{2}$ Ethnic minority candidates get a score of 1 if in the survey they indicated that at least one of their parents were born outside of the EU. In order to operationalize political experience I use different measures. I make a distinction between legislative experience at the local level, executive experience at the local level, experience as mayor, experience in one of the three parliaments (regional, federal or European) and experience as a minister at either the Flemish or federal level. These are all dummy variables where candidates score a 1 if in the survey they indicated that they ever were in that function. Finally, information about a candidate's ballot list position is obtained through the official electoral list, whereas for the variable media attention, I gathered data using GoPress, a Belgian digital database which archives all newspapers. For each candidate I counted the number of newspaper articles in which they were mentioned in the month before the elections for nine Flemish newspapers. ${ }^{3}$

\footnotetext{
2 There were no candidates with a different gender identity.

${ }^{3}$ The broadsheets De Morgen, De Standaard and De Tijd, the popular newspapers Het Laatste Nieuws and Het Nieuwsblad, and the regional newspapers Het Belang van Limburg, Krant van West-Vlaanderen and Gazet van Antwerpen and the free daily Metro.
} 
Next to the main models hypothesis 2 and 3 are tested by adding interactions between the ideological distance measures and respectively issue ownership and whether or not the candidate occupied a top position on the list. To include a measure for (associative) issue ownership, an online representative voter survey ( $\mathrm{N}=960)$ is used ([Author], 2017). In this survey, respondents were asked to indicate for each dimension which specific party came to mind when thinking about it. These responses are aggregated to determine which party respondents associated the most with a specific dimension. In the end, the Greens are coded as owners on environment, the regionalist party on federalism, the liberals on economy, and the populist radical right party on immigration. In all cases, at least $25 \%$ of the voters associated that party with the sub-dimension [Author] (2017). For the ethical dimension, no clear owner is appointed, as the parties are very close to each other. Finally, to operationalize top and ordinary candidates, a combination of party magnitude and ballot list position is used. Party magnitude, the number of seats a party won in a district, is used to determine who the realistic candidates are. For smaller parties in smaller districts there is only one realistic candidate, whereas for large parties in large districts there can be up to seven. However, ballot list position is used to limit the realistic candidates to maximum the first three positions on the ballot list.

The dataset has a nested structure where candidates are embedded in party lists which are nested in political parties and electoral districts. I account for this structure by first of all adding fixed effects for political parties and electoral districts. Second, I control for four variables at the party list level: 1) list magnitude, operationalized as the number of candidates on the party ballot list, 2) electoral strength, operationalized as the number of seats won by the party in a district, 3) the percentage of voters casting a preferential vote instead of a list vote at the list level, 4) the average number of preferential votes cast by preferential voters for the list. As the inclusion of these control variables at the party list level opens up a second level, I use linear multilevel models. Finally, I also include a dummy for whether the candidate participated at the Flemish or federal level. However, no clear differences are expected between these two levels, as both elections are in general seen to be of a first-order nature.

\section{Results}

Before testing the electoral effect of ideological positioning, it is useful to first get an idea whether candidates actually deviate from the party line. Figure 1 gives an overview of the ideological distribution of candidates per dimension per party. It shows that there indeed exists variation within parties. Parties are not homogenous actors with candidates who all think alike. Rather, the ideological distribution within parties is fairly heterogeneous. For instance, on the issue of economy the figure 
shows that candidates from left-wing parties are mostly left on the dimension and candidates from right-wing parties are more right. However, some candidates are more moderate than their party and others are more extreme. The figure also shows that the extent to which parties are heterogeneous varies per party and per dimension. Especially within the Christian democratic party, candidates seem to take different positions. This is not surprising given the catch-all nature of this party. Also parties seem to be more homogenous on their core issues (e.g. the Greens on environment) and more diverse on dimensions that matter less to them.

[Figure 1]

The question is to what extent these ideological differences translate to the electoral outcome. In model 1 Table 1 the effect of the absolute distance between candidates and their party on the different ideological dimensions is tested. The model clearly shows that the candidate's ideological position does not affect the proportion of preferential votes one receives. Although (most of) the coefficients would suggest that candidates further removed from their party's official line receive less votes, none of the six dimensions come close to statistical significance, and therefore both hypotheses $1 \mathrm{a}$ and $1 \mathrm{~b}$, which expected respectively a positive and negative effect, can be rejected. An alternative option is that the effect is curvilinear. Model 2 in Table 2 therefore adds quadratic terms for the separate dimensions. Yet, also in this model no ideological effects are found. We can thus conclude that there is no direct effect of absolute ideological distance on the individual electoral success of a candidate.

\section{[Table 1 and 2]}

Of course, it could be that the effect only works for certain candidates. Therefore, an interaction is added between top candidates and the absolute ideological distance in model 3. Again no significant effects are found. Not even top candidates, for whom more information regarding their ideological position may be available, get electorally rewarded or punished for deviating from the party line. Hypothesis 2 should therefore also be rejected. Model 4 tests hypotheses $3 \mathrm{a}$ and $3 \mathrm{~b}$ which expect that deviating from the party may have a negative effect on owned issues and a positive effect on notowned issues. Yet, again none of the interaction terms with issue ownership are significant, indicating that on owned issues deviating from the party line has no electoral consequences either.

The previous analyses only focused on absolute distances without taking into account the direction. Therefore, in Table 3 I run the same analyses this time using the directional ideological distance in such a way that a negative score means that the candidate takes a more left stance than 
the party and a positive score that the candidate is more right-wing on that dimension. Model 5 and 6 show that the findings remain the same to a large extent and that hypotheses $1 a$ and $b$ have to be rejected. The only exception is that this time there is a significant effect for the ethical dimension. Candidates who position themselves more conservative on the ethical dimension perform electorally less well. It is slightly puzzling why there is an effect on the ethical dimension and not for the other dimensions. However, when inspecting this effect in more detail it seems that it is fully driven by one outlier. One candidate is more than six standard deviations removed from the average position of his party on this dimension. Also the Cook's D score of this candidate is way above the threshold value of $4 /(n-k-1)$, indicating that is an influential outlier as well. Once this candidate is omitted, the effect of the ethical dimension is no longer significant. This outlier could indicate that in certain extreme cases where candidates are totally out of line with their party, they will be electorally punished. However, it is also possible that this relation is spurious with another factor driving the extreme position of the candidate. Given that the candidate was not a well-known candidate - in the advent to the elections he did not appear in any newspaper article - making it unlikely that voters were aware of his ideological position, and given that for the other dimensions we do not find that the ideological outliers are electorally punished, this latter explanation seems more plausible. However, when running extra robustness tests below I will test for the possibility that in certain cases where a candidate takes an extremely deviating position in the party, ideological position does influence individual electoral success.

\section{[Table 3]}

Model 7 adds an interaction between directional ideological distance and top candidates. With the exception of (again) the ethical dimension it finds no evidence that there is an effect for top candidates and therefore does not support hypothesis 2 . Like model 4 , in model 8 there is also no significant interaction between deviating ideologically and issue ownership. So in general using a directional measure rather than an absolute measure, shows the same pattern and none of the hypotheses are supported.

All in all, focusing on the separate dimensions and investigating both the absolute distance and the directional distance, there are almost no situations in which ideology matters. Also testing alternatives that it only matter for certain candidates from certain parties on owned issues did not yield any significant results. Rather, the usual factors such as ballot list position, political experience and socio-demographic characteristics impact the electoral fortune of candidates the most. The only 
exception seems to be the ethical dimension where the results indicate that candidates may get punished for being too conservative, but this effect seems to be driven by a single outlier.

In appendix B extra robustness checks are conducted. First, I test what happens when ideological distance is standardized to take into account the ideological distribution within the party (Model A and B in Table B1 and B2), but this does not result in any different findings. Second, I test whether in certain cases where candidates take an extremely deviating position from the party, ideology may play a role after all, as the previous finding around the ethical dimension suggest this may be the case. Therefore, rather than adding the ideological variables as continuous variables, I add them as dichotomous variables to the model where candidates score a 1 if they take an ideological position that is more than two standard deviations away from the average party position. However, model C in Table B3 shows that these dummies do not have a statistical significant effect. Thus, I find no further evidence that ideology does play a role for those candidates that take an extremely deviating position from the party. Third, rater than looking at the six ideological dimensions separately, I examine what happens when I use an aggregate scale that measures the combined distance on all six dimensions simultaneously instead (model D). This measure is created by computing the Euclidean distance on the combined six dimensions. ${ }^{4}$ Nevertheless, again the findings are very similar, as also this combined measure, that indicates general extent to which a candidate ideological from the party line, has no statistical effect on individual electoral success. Fourth, model E and G (Table B3 and B4) test what happens when rather than using a dichotomous categorization of issue ownership, the percentage of voters associating the party with the dimension is used. Also when using this measure no support is found for hypotheses $3 a$ and $b$. Finally, model $F$ and $H$ test what happens when we take into account the importance the electorate of a party gives to each dimension. In the voter survey all voters were asked how important they find each dimension on a scale from 1 to 7 . I aggregated these scores per party and interacted them with ideological distance. Yet, none of the interactions are significant and there is no ideological effect. In general, like the main models, these models all indicate that candidates' ideological position vis-à-vis the party do not really matter to voters and cannot explain differences between candidates' individual electoral success.

\section{Conclusion and discussion}

The aim of this study was to assess the extent to which the ideological position of candidates within their party impacts individual electoral success. Previous studies have mostly ignored this factor and

\footnotetext{
${ }^{4}$ Concretely, this means that for each dimension I square the difference between the position of the candidate and the average position of the party, which I then summate. I then take the square root of this sum.
} 
this research therefore served as a first investigation. The study assessed the direct effect of a candidate's ideological position on his or her obtained preferential votes, but also tested whether ideology perhaps only matters for certain candidates on certain issue dimensions. The main conclusion is that in none of the situations was there any significant effect of a candidate's ideological position vis-à-vis the party on electoral success. Even when using alternative operationalizations or when taking into account the importance of a dimension or the distinction between top and ordinary candidates, no effects were found. Thus, this study clearly shows that in the intra-party competition for preferential votes candidates' personal ideology do not matter. Rather, factors such as ballot list position, socio-demographic factors and political experience determine the proportion of preferential votes.

How can we explain these non-findings? One explanation is that voting for candidates on the basis of their ideology is cognitive demanding. While voters may act rational, this rationality is bounded. Often voters already have problems to know which position parties take on different ideological dimensions (Dejaeghere \& van Erkel, 2017), let alone where their individual candidates stand. Additionally, this information is often simply not available. Most candidates do not individually present an ideological platform and also in the media there is usually no coverage about the ideological position of a candidate, unless it really leads to conflict within the party. An alternative explanation is that voters know that (elected) candidates have little impact on the party position, given that party unity in the Belgian context is very high.

Of course, this study only served as a first exploration. For example, it focused exclusively on candidates without taking into account voter data. One avenue for future research would therefore be to link voter and candidate data and assess whether the likelihood of a preferential vote increases when voter and candidate are ideologically closer. Another factor this study overlooked is salience. Although voters may not give their vote to candidates that deviate from the party line, they may vote for candidates that campaign more on the issues that they find salient. A party's spokesperson on defense, for instance, may receive more votes from a citizen that finds this the most important issue. Unfortunately, the data do not allow me to test this, but future studies should look into it. Finally, it is possible that diverging from the official party line may have an impact in cases where this dissent is very visible in the press. In these situations voters may be more aware of the unique position of the candidate in the party and be more likely to reward or punish the candidate for it. While in the analysis I did include a variable for the amount of media attention, this variable is quite crude and does not give any insight in whether anything is said about the candidate's ideological position. An avenue for future research would therefore be to conduct a more extensive media analysis and test whether 
dissenting from the party line does have an effect on individual electoral success when this dissent receives media attention.

The finding that the ideological position of candidates does not matter for their individual electoral success points to some broader implications and is important for three reasons. First, for candidates it shows that ideology is not a relevant PVEA attribute and that they cannot really win (or lose) votes by taking an ideological niche position within the party. Rather, they will need to win votes in other ways, for instance by emphasizing more personal traits such as their political experience, locality, or ethnical background. Second, the results further support the conclusion of van Holsteyn \& Andeweg (2010) and André et al. (2017) that preferential votes are usually embedded in a party vote. We know that ideology plays, to some extent, a role in the consideration to vote for a party, but this study shows that it does not seem to influence preferential voting. In other words, voters seem to pick a party first (partly) based on ideology and then use other factors such as ballot list position, sociodemographic characteristics and political experience to vote for a candidate within that party. Third, and perhaps most important, the findings of this study provide better insight in how and why voters use preferential votes. Whereas we know from previous research from among others Marien et al. (2017) and van Erkel (2019) that preferential votes have an important signaling function and that voters use them to support certain marginalized groups or local candidates and in that way try to influence the (socio-demographic) composition of parliament, this study demonstrates that citizens do not use preferential votes in a similar way to signal their party on its ideological position. Whereas we may have expected that preferential votes can also serve as an instrument for voters to change the ideological line of the party, ultimately this study shows that they are not used in that way.

\section{Bibliography}

Alvarez, R.M., \& Nagler, J. (1998). When Politics and Models Collide: Estimating Models of Multiparty Elections. American Journal of Political Science,42(1),55-96.

Andeweg, R. B., \& Thomassen, J. (2011). Pathways to party unity: Sanctions, loyalty, homogeneity and division of labour in the Dutch parliament. Party Politics,17(5),655-672.

André, A., Depauw, S. \& Pilet, J-B. (2017). The nature of preference voting: Disentangling the party and personal components of candidate choice. In Deschouwer, K. (Red.), Mind the gap: Political participation and representation in Belgium (pp.251-274). ECPR Press. 
André, A., Depauw, S., Shugart, M.S., \& Chytilek, R. (2017). Party nomination strategies in flexible-list systems: Do preference votes matter? Party Politics,23(5),589-600.

Bowler, S. (2010). Private Members' Bills in the UK Parliament: Is There an 'Electoral Connection'? The Journal of Legis/ative Studies,16(4),476-494.

Carey J.M. \& Shugart, M.S. (1995). Incentives to cultivate a personal vote: a rank-ordering of electoral formulas. Electoral Studies,14(4),417-439.

Ceron, A. (2015). Brave rebels stay home: Assessing the effect of intra-party ideological heterogeneity and party whip on roll-call votes. Party Politics,21(2),246-258.

Dejaeghere, Y., \& van Erkel, P. (2017). The importance of issue-ownership and salience for voters' knowledge of parties' issue positions. Electoral Studies,46,15-25.

Deschouwer, K. (2012). The politics of Belgium: Governing a divided society. Palgrave MacMillan.

Downs, A. (1957). An Economic Theory of Democracy. Harper \& Row.

Folke, O., Persson, T., \& Rickne, J. (2016). The Primary Effect: Preference Votes and Political Promotions. American Political Science Review,110(3),559-578.

Green, J., \& Hobolt, S.B. (2008). Owning the issue agenda: Party strategies and vote choices in British elections. Electoral Studies,27(3),460-476.

Laver, M., \& Schofield, N. (1998). Multiparty Government: The Politics of Coalition in Europe. University of Michigan Press.

Lesschaeve, C., van Erkel, P.F.A. \& Meulewaeter, C. (2018). Thinking alike: Two pathways to leadershipcandidate opinion congruence. Journal of Elections, Public Opinion and Parties,28(4),488-515.

Maddens, B., Wauters, B., Noppe, J., \& Fiers, S. (2006). Effects of Campaign Spending in an Open List PR System: The 2003 Legislative Elections in Flanders/Belgium. West European Politics, 29(1),161-168.

Marcinkiewicz, K., \& Stegmaier, M. (2015). Ballot Position Effects Under Compulsory and Optional Preferential-List PR Electoral Systems. Political Behavior,37(2),465-486. 
Marien, S., Schouteden, A., \& Wauters, B. (2017). Voting for Women in Belgium's Flexible List System. Politics \& Gender,13(2),305-335.

May, J. (1973). Opinion Structure of Political Parties: The Special Law of Curvilinear Disparity. Political Studies,21(2),135-151.

Müller, W.C., \& Strøm, K. (1999). Political parties and hard choices. In W.C. Müller \& K. Strøm (Red.), Policy, Office, or Votes? How Political Parties in Western Europe Make Hard Choices (pp.1-36). Cambridge University Press.

Norris, P., Curtice, J., Scammell, M., \& Semetko, H.A. (1999). On Message: Communicating the Campaign. Sage.

Petrocik, J.R. (1996). Issue Ownership in Presidential Elections, with a 1980 Case Study. American Journal of Political Science,40(3),825-850.

Put, G.-J., \& Maddens, B. (2013). The Selection of Candidates for Eligible Positions on PR Lists: The Belgian/Flemish Federal Elections 1999-2010. Journal of Elections, Public Opinion and Parties, $23(1), 49-65$.

Put, G.-J., Smulders, J., \& Maddens, B. (2019). How local personal vote-earning attributes affect the aggregate party vote share: Evidence from the Belgian flexible-list PR system (2003-2014). Politics,39(4),464-479.

Sartori, G. (1976). Parties and Party Systems: A Framework for Analysis. Cambridge University Press.

Shugart, M.S., Valdini, M.E, \& Suominen, K. (2005). Looking for locals: Voter information demands and personal vote-earning attributes of legislators under proportional representation. American Journal of Political Science,49(2).437-449.

Van Erkel, P.F.A., \& Thijssen, P. (2016). The first one wins: Distilling the primacy effect. Electoral Studies, $44,245-254$.

Van Erkel, P.F.A. (2019). Sharing is caring: The role of voter-candidate similarities in intra-party electoral competition. European Political Science Review,11(1),75-89. 
Van Haute, E. \& Carty, R.K. (2012). Ideological misfits: A distinctive class of party members. Party Politics,18(6),885-895.

Van Holsteyn, J.J.M., \& Andeweg, R.B. (2010). Demoted leaders and exiled candidates: Disentangling party and person in the voter's mind. Electoral Studies,29(4),628-635.

Van Holsteyn, J.J., Ridder, J.M.D., \& Koole, R.A. (2017). From May's Laws to May's legacy: On the opinion structure within political parties. Party Politics,23(5),471-486.

Vegetti, F., Fazekas, Z., \& Méder, Z.Z. (2017). Sorting your way out: Perceived party positions, political knowledge, and polarization. Acta Politica,52(4),479-501.

Wauters, B., Verlet, D., \& Ackaert, J. (2012). Giving More Weight to Preferential Votes: Welcome or Superfluous Reform? The Case of the Local Elections in Flanders (Belgium). Local Government Studies,38(1),91-111. 


\section{Tables and Figures}

Table 1:Absolute ideological distance

\begin{tabular}{|c|c|}
\hline & Model 1 \\
\hline Absolute distance:economy & $-.004(.01)$ \\
\hline Absolute distance:environment & $.006(.01)$ \\
\hline Absolute distance:Europe & $-.004(.01)$ \\
\hline Absolute distance:migration & $.000(.01)$ \\
\hline Absolute distance:ethics & $-.005(.01)$ \\
\hline Absolute distance:federalism & $-.007(.00)$ \\
\hline Age & $-.002(.00)$ \\
\hline Female & $.251(.02)^{* *}$ \\
\hline Ethnic minority & $.177(.04)^{* *}$ \\
\hline First candidate & $1.133(.05)^{* *}$ \\
\hline Ballot list position & $.036(.00)^{* *}$ \\
\hline Last candidate & $.571(.05)^{* *}$ \\
\hline Local council & $.076(.02)^{* *}$ \\
\hline Alderman & $-.005(.02)$ \\
\hline Mayor & $.133(.04)^{* *}$ \\
\hline Experience Flemish parliament & $.230(.04)^{* *}$ \\
\hline Experience Federal parliament & $.305(.04)^{* *}$ \\
\hline Experience European parliament & $.627(.16)^{*}$ \\
\hline Minister & $.239(.06)^{* *}$ \\
\hline Media coverage $(\log )$ & $.024(.00)^{* *}$ \\
\hline Federal election & $1.221(.20)^{* *}$ \\
\hline List magnitude & $.120(.03)^{* *}$ \\
\hline Electoral strength & $.014(.02)$ \\
\hline$\%$ of preferential votes & $.002(.00)$ \\
\hline Average \# of preferential votes & $.876(.16)^{* *}$ \\
\hline \multicolumn{2}{|l|}{ Party (ref=Christian democratic party) } \\
\hline - Regionalist party & $.661(.13)^{* *}$ \\
\hline - $\quad$ Green party & $-.463(.11)^{* *}$ \\
\hline Social-democratic party & $-.229(.09)^{* *}$ \\
\hline - $\quad$ Liberal party & $-.260(.09)^{* *}$ \\
\hline - Far-right & $-.875(.13)^{* *}$ \\
\hline - $\quad$ Socialist party & $-1.621(.13)^{* *}$ \\
\hline Constant & $-10.782(1.00)^{* *}$ \\
\hline$\sigma_{\text {candidate }}$ & .026 \\
\hline$\sigma_{\text {residual }}$ & .065 \\
\hline $\mathrm{N}$ (candidates) & 899 \\
\hline N(Lists) & 70 \\
\hline
\end{tabular}

Note: Fixed effects and main issue ownership variables are not depicted 
Table 2:Interaction effects

\begin{tabular}{|c|c|c|c|}
\hline & Model 2 & Model 3 & Model 4 \\
\hline Absolute distance:economy & $-.002(.01)$ & $-.007(.01)$ & $-.004(.01)$ \\
\hline Absolute distance:environment & $.011(.01)$ & $.002(.01)$ & $.007(.01)$ \\
\hline Absolute distance:Europe & $-.014(.01)$ & $-.002(.01)$ & $-.005(.01)$ \\
\hline Absolute distance:migration & $.014(.01)$ & $-.001(.01)$ & $.001(.01)$ \\
\hline Absolute distance:ethics & $-.004(.01)$ & $-.002(.01)$ & $-.005(.00)$ \\
\hline Absolute distance:federalism & $-.014(.01)$ & $-.009(.01)$ & $-.007(.01)$ \\
\hline Absolute distance:economy² & $-.000(.00)$ & & \\
\hline Absolute distance:environment ${ }^{2}$ & $-.001(.00)$ & & \\
\hline Absolute distance:Europe ${ }^{2}$ & $.001(.00)$ & & \\
\hline Absolute distance:migration ${ }^{2}$ & $-.002(.00)$ & & \\
\hline Absolute distance:ethics ${ }^{2}$ & $-.000(.00)$ & & \\
\hline Absolute distance:federalism ${ }^{2}$ & $.001(.00)$ & & \\
\hline Top candidate & & $.946(.09)^{* *}$ & \\
\hline Top candidate*economy & & $.010(.02)$ & \\
\hline Top candidate*environment & & $-.042(.03)$ & \\
\hline Top candidate*Europe & & $.019(.02)$ & \\
\hline Top candidate*migration & & $-.044(.02)$ & \\
\hline Top candidate* ${ }^{*}$ ethics & & $-.049(.01)$ & \\
\hline Top candidate*federalism & & $-.006(.02)$ & \\
\hline Owner economy*economy & & & $.006(.01)$ \\
\hline Owner environment*environment & & & $-.001(.01)$ \\
\hline Owner Europe*Europe & & & $.010(.01)$ \\
\hline Owner migration*migration & & & $-.004(.02)$ \\
\hline Owner federalism*federalism & & & $-.000(.02)$ \\
\hline Constant & $-10.732(1.00)^{* *}$ & $-10.648(1.01)^{* *}$ & $-12.406(.99)$ \\
\hline$\sigma_{\text {candidate }}$ & .026 & .024 & .026 \\
\hline$\sigma_{\text {residual }}$ & .064 & .087 & .065 \\
\hline $\mathrm{N}$ (candidates) & 899 & 899 & 899 \\
\hline N(Lists) & 70 & 70 & 70 \\
\hline
\end{tabular}

$* \mathbf{p}<.05 ; * * \mathbf{p}<.01$

Note: Fixed effects, control variables and main issue ownership variables are not depicted 


\begin{tabular}{|c|c|c|c|c|}
\hline & Model 5 & Model 6 & Model 7 & Model 8 \\
\hline Directional distance:economy & $.000(.00)$ & $.001(.00)$ & $.002(.00)$ & $.002(.00)$ \\
\hline Directional distance:environment & $.001(.00)$ & $-.000(.00)$ & $.002(.01)$ & $.000(.00)$ \\
\hline Directional distance:Europe & $-.002(.00)$ & $-.002(.00)$ & $-.002(.00)$ & $-.000(.00)$ \\
\hline Directional distance:migration & $-.003(.00)$ & $-.003(.00)$ & $-.006(.01)$ & $-.002(.00)$ \\
\hline Directional distance:ethics & $-.005(.00)^{*}$ & $-.004(.00)$ & $.000(.00)$ & $-.005(.00)$ \\
\hline Directional distance:federalism & $.001(.00)$ & $.000(.00)$ & $-.002(.00)$ & $-.001(.00)$ \\
\hline Directional distance:economy² & & $-.000(.00)$ & & \\
\hline Directional distance:environment ${ }^{2}$ & & $.001(.00)$ & & \\
\hline Directional distance:Europe ${ }^{2}$ & & $.000(.00)$ & & \\
\hline Directional distance:migration ${ }^{2}$ & & $.000(.00)$ & & \\
\hline Directional distance:ethics ${ }^{2}$ & & $-.000(.00)$ & & \\
\hline Directional distance:federalism² ${ }^{2}$ & & $-.001(.00)$ & & \\
\hline Top candidate & & & $.741(.05)^{* *}$ & \\
\hline Top candidate*economy & & & $.007(.01)$ & \\
\hline Top candidate*environment & & & $.013(.02)$ & \\
\hline Top candidate*Europe & & & $.026(.02)$ & \\
\hline Top candidate*migration & & & $.001(.02)$ & \\
\hline Top candidate*ethics & & & $-.022(.01)^{*}$ & \\
\hline Top candidate*federalism & & & $-.025(.02)$ & \\
\hline Owner economy*economy & & & & $-.009(.01)$ \\
\hline Owner environment*environment & & & & $-.002(.01)$ \\
\hline Owner Europe*Europe & & & & $-.012(.01)$ \\
\hline Owner migration*migration & & & & $-.003(.01)$ \\
\hline Owner federalism*federalism & & & & $-.005(.01)$ \\
\hline Constant & $-10.732(1.00)^{* *}$ & $-10.739(1.00)^{* *}$ & $-10.441(1.00)^{* *}$ & $-11.128(1.84)$ \\
\hline$\sigma_{\text {candidate }}$ & .026 & .026 & .023 & .104 \\
\hline$\sigma_{\text {residual }}$ & .065 & .065 & .090 & .064 \\
\hline $\mathrm{N}$ (candidates) & 899 & 899 & 899 & 899 \\
\hline N(Lists) & 70 & 70 & 70 & 70 \\
\hline
\end{tabular}

$* \mathbf{p}<.05 ; * * \mathbf{p}<.01$

Note: Fixed effects, control variables and the main issue ownership variables are not depicted. 
Figure 1:0verview of ideological distributions
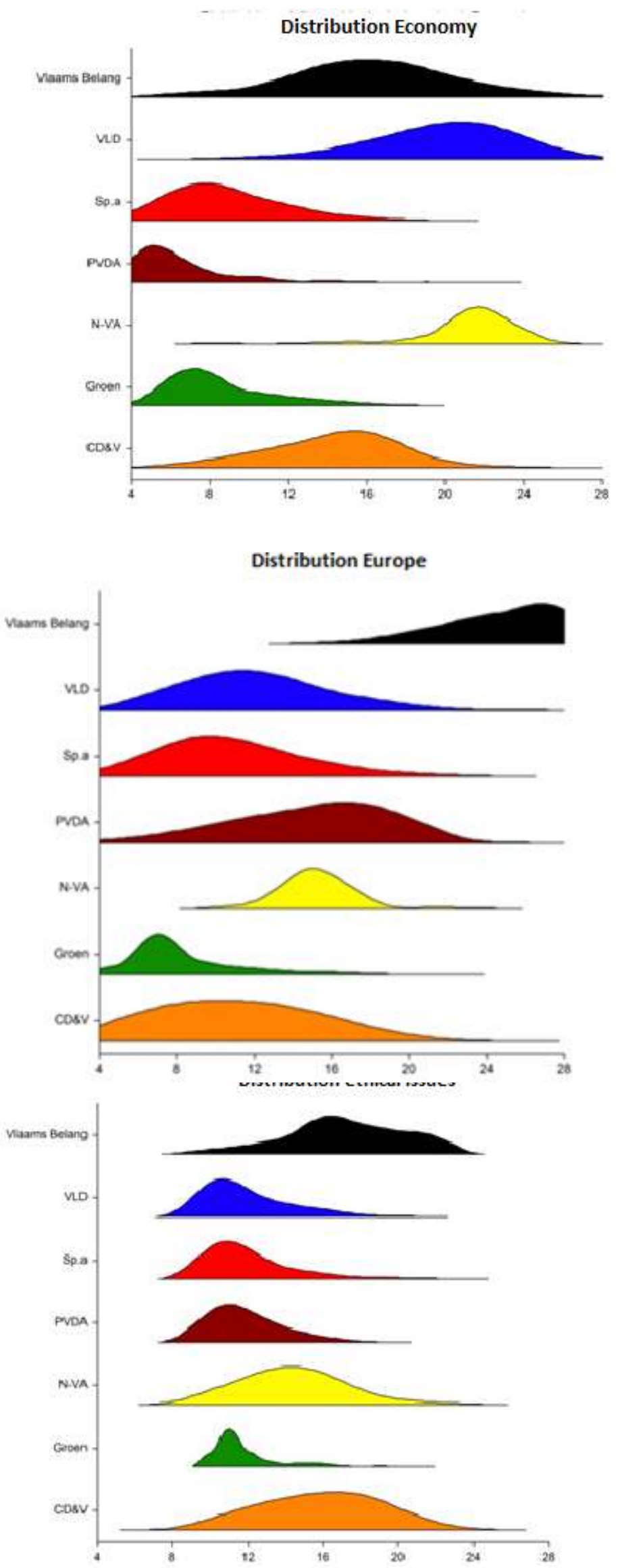

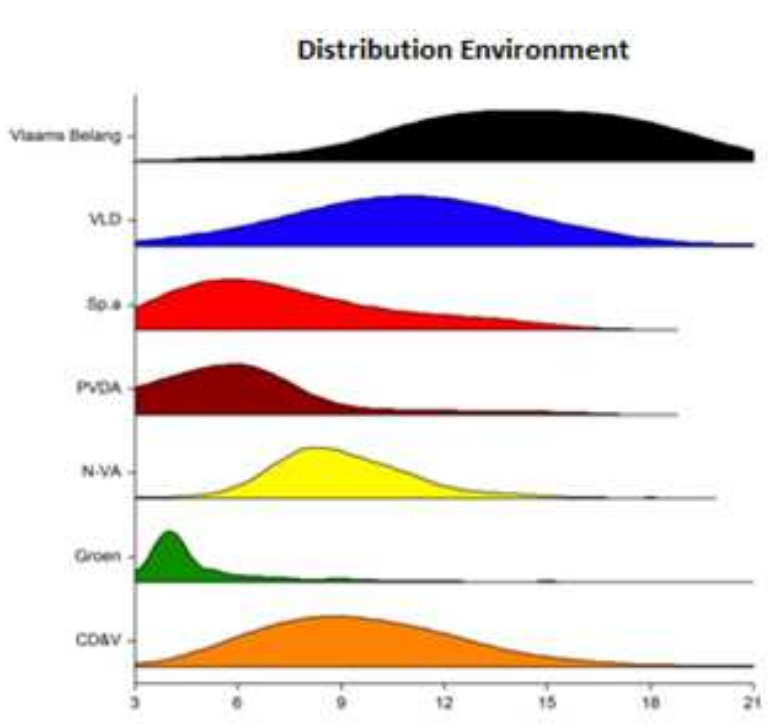

Distribution Migration
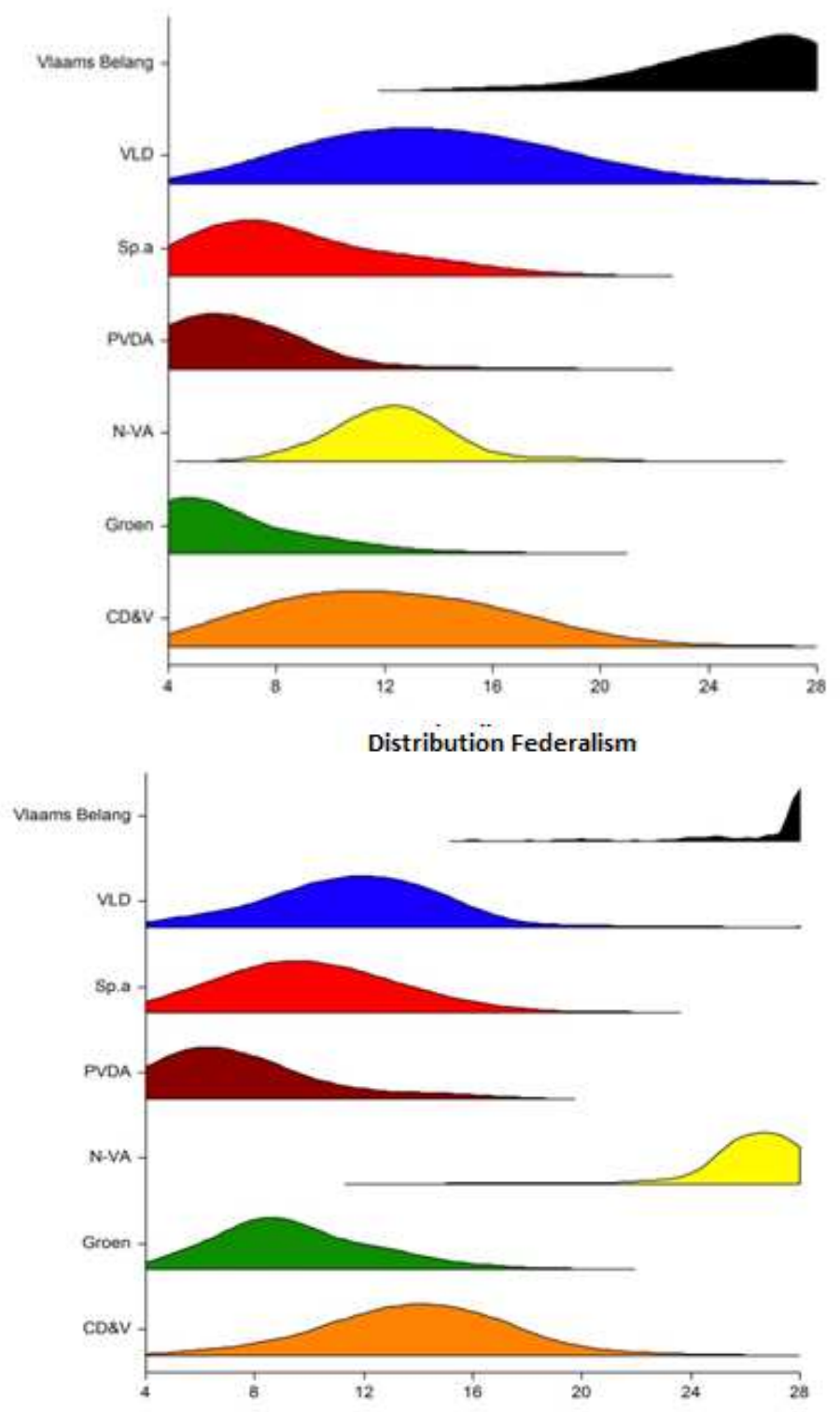
Appendix A: Overview of the issue dimension scales

\begin{tabular}{l|l} 
Item & Economy \\
\hline $\begin{array}{l}\text { The government should interfere to reduce } \\
\text { differences between incomes (reversed) }\end{array}$ & .877 \\
$\begin{array}{l}\text { The government should enforce as few rules as } \\
\text { possible }\end{array}$ & .883 \\
$\begin{array}{l}\text { The interests of the working class should be } \\
\text { defended more (reversed) }\end{array}$ & .744 \\
$\begin{array}{l}\text { The government should interfere less in the } \\
\text { economy }\end{array}$ & .860 \\
\hline Cronbach's alpha & .870
\end{tabular}

\begin{tabular}{l|l} 
Item & Environment \\
\hline $\begin{array}{l}\text { The benefits of sustainable energy are being } \\
\text { overrated }\end{array}$ & .856 \\
$\begin{array}{l}\text { The dangers of climate change are } \\
\text { exaggerated }\end{array}$ & .846 \\
$\begin{array}{l}\text { Rules regarding the environment should not } \\
\text { harm the economy }\end{array}$ & .741 \\
\hline Cronbach's alpha & .747
\end{tabular}

\begin{tabular}{l|l} 
Item & Europe/international \\
\hline $\begin{array}{l}\text { The European unification should not go any } \\
\text { further }\end{array}$ & .865 \\
Belgium has received many benefits from its & .763 \\
EU membership (reversed) & \\
We should first solve our own problems before & .826 \\
we help other European countries with & \\
economic problems & \\
$\begin{array}{l}\text { We should share our wealth with poorer } \\
\text { countries, even if it means we lose some } \\
\text { wealth (reversed) }\end{array}$ & .657 \\
\hline Cronbach's alpha & .786
\end{tabular}

\begin{tabular}{l|l} 
Item & Immigration \\
\hline Migrants make too much use of social benefits & .844 \\
$\begin{array}{l}\text { Migrants contribute to the wealth of our } \\
\text { society (reversed) }\end{array}$ & .904 \\
$\begin{array}{l}\text { Migrants form a threat for our society } \\
\text { Belgium should close its borders for asylum }\end{array}$ & .870 \\
seekers & .858 \\
\hline Cronbach's alpha & .886
\end{tabular}




\begin{tabular}{l|l} 
Item & Ethics \\
\hline $\begin{array}{l}\text { The government should make more strict rules } \\
\text { on euthanasia }\end{array}$ & .869 \\
$\begin{array}{l}\text { Women should always be able to abort their } \\
\text { pregnancy (recoded) }\end{array}$ & .787 \\
$\begin{array}{l}\text { Marriage should only be possible between a } \\
\text { man and a woman }\end{array}$ & .710 \\
$\begin{array}{l}\text { You should always be allowed to decide on } \\
\text { your life's end (recoded) }\end{array}$ & .822 \\
\hline Cronbach's alpha & .809 \\
\hline \begin{tabular}{l|l} 
Item & Federal \\
\hline $\begin{array}{l}\text { Flanders should receive more competencies } \\
\text { The federal state is the most competent to run } \\
\text { diplomatic relations with foreign countries } \\
\text { (recoded) }\end{array}$ & .876 \\
Belgium should stay in existence (recoded) \\
I feel more Belgian than Flemish (recoded)
\end{tabular} & .915 \\
\hline \begin{tabular}{l} 
Cronbach's alpha \\
\hline
\end{tabular} & .926 \\
\hline
\end{tabular}




\section{Appendix B: Robustness tests}

Table B1: The effect of the standardized absolute ideological distance on individual electoral success

\begin{tabular}{l|c} 
Individual electoral success (log) & Model A \\
\hline Standardized absolute distance: economy & $-.006(.01)$ \\
Standardized absolute distance: & $.017(.01)$ \\
environment & $-.012(.01)$ \\
Standardized absolute distance: Europe & $.003(.02)$ \\
Standardized absolute distance: migration & $-.020(.02)$ \\
Standardized absolute distance: ethics & $-.020(.01)$ \\
Standardized absolute distance: federalism & 899 \\
\hline N (candidates) & 70
\end{tabular}

${ }^{*} \mathbf{p}<.05 ; * * \mathbf{p}<.01$

Note: Control variables are not depicted

Table B2: The effect of the standardized directional ideological distance on individual electoral success

\begin{tabular}{l|c} 
Individual electoral success (log) & Model B \\
\hline Standardized directional distance: economy & $.002(.01)$ \\
Standardized directional distance: & $.002(.01)$ \\
environment & \\
Standardized directional distance: Europe & $-.004(.01)$ \\
Standardized directional distance: migration & $-.010(.01)$ \\
Standardized directional distance: ethics & $-.021(.01)^{*}$ \\
Standardized directional distance: & $.002(.01)$ \\
federalism & \\
\hline N (candidates) & 709 \\
N (Party Lists) & 70
\end{tabular}

${ }^{*} \mathbf{p}<.05 ;{ }^{* *} \mathbf{p}<.01$

Note: Control variables are not depicted 
Table B3: Extra tests absolute distance

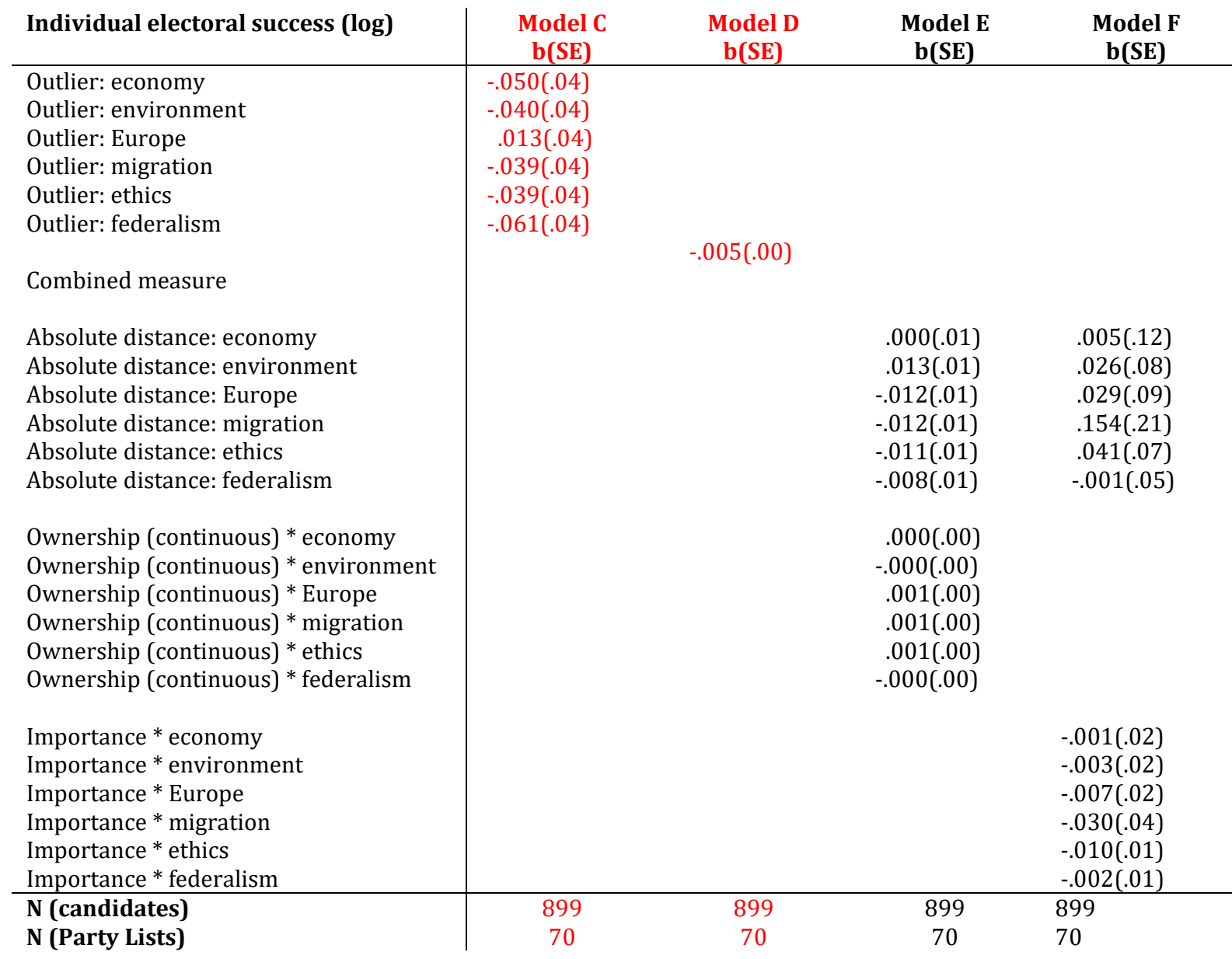

${ }^{*} \mathbf{p}<.05 ;{ }^{* *} \mathbf{p}<.01$

Note: Fixed effects for electoral districts, control variables and the main issue ownership variables are not depicted 
Table B4: Extra tests directional distance

\begin{tabular}{l|cc} 
Individual electoral success (log) & $\begin{array}{c}\text { Model G } \\
\mathbf{b}(\mathbf{S E})\end{array}$ & $\begin{array}{c}\text { Model H } \\
\mathbf{b ( S E )}\end{array}$ \\
\hline Directional distance: economy & $.003(.01)$ & $.006(.08)$ \\
Directional distance: environment & $.001(.00)$ & $-.020(.06)$ \\
Directional distance: Europe & $.003(.01)$ & $.018(.05)$ \\
Directional distance: migration & $-.002(.01)$ & $.043(.13)$ \\
Directional distance: ethics & $-.003(.01)$ & $.048(.04)$ \\
Directional distance: federalism & $.003(.01)$ & $-.021(.03)$ \\
& & \\
Ownership (continuous) * economy & $-.000(.00)$ & \\
Ownership (continuous) * environment & $-.004(.00)$ & \\
Ownership (continuous) * Europe & $-.000(.00)$ & \\
Ownership (continuous) * migration & $.000(.01)$ & \\
Ownership (continuous) * ethics & $-.000(.00)$ & \\
Ownership (continuous) * federalism & $-.000(.00)$ & \\
& & $-.001(.01)$ \\
Importance * economy & & $.004(.01)$ \\
Importance * environment & & $-.005(.01)$ \\
Importance * Europe & & $-.009(.02)$ \\
Importance * migration & & $-.012(.01)$ \\
Importance * ethics & & $.006(.01)$ \\
Importance * federalism & & 899 \\
\hline $\mathbf{N}$ (candidates) & & 70 \\
N (Party Lists) & &
\end{tabular}

\section{$* \mathbf{p}<.05 ; * * \mathbf{p}<.01$}

Note: Fixed effects for electoral districts, control variables and the main issue ownership variables are not depicted 